University of Nebraska - Lincoln

DigitalCommons@University of Nebraska - Lincoln

Agronomy \& Horticulture -- Faculty Publications

Agronomy and Horticulture Department

$10-1925$

\title{
Transect Method of Studying Woodland Vegetation Along Streams
}

J. E. Weaver

University of Nebraska-Lincoln

Herbert Hanson

John Aikman

Follow this and additional works at: https://digitalcommons.unl.edu/agronomyfacpub

Part of the Plant Sciences Commons

Weaver, J. E.; Hanson, Herbert; and Aikman, John, "Transect Method of Studying Woodland Vegetation Along Streams" (1925). Agronomy \& Horticulture -- Faculty Publications. 430.

https://digitalcommons.unl.edu/agronomyfacpub/430

This Article is brought to you for free and open access by the Agronomy and Horticulture Department at DigitalCommons@University of Nebraska - Lincoln. It has been accepted for inclusion in Agronomy \& Horticulture -Faculty Publications by an authorized administrator of DigitalCommons@University of Nebraska - Lincoln. 


\section{TRANSECT METHOD OF STUDYING WOODLAND VEGETATION ALONG STREAMS}

J. E. Weaver, Herbert C. Hanson, and John M. Atiman

\section{(WITH ELEVEN FIGURES)}

In pursuance of an investigation of competition among certain shrubs (Rhus glabra, ${ }^{\mathbf{x}}$ Corylus americana, Symphoricarpos spp.), and between these shrubs and Quercus macrocarpa, it became imperative, for a proper understanding of their behavior, to ascertain just how near the edge of their range they were growing. The station, which is located at Weeping Water, Nebraska, is on the Weeping Water River, a branch of the Missouri, I 5 miles west of its mouth. This stream arises 15 miles farther west, and in general its course parallels that of the Platte River about I 5 miles north. As is generally the case throughout eastern Nebraska, chaparral and woodland are confined to the vicinity of the stream courses. Rather than following the meandering stream throughout its length, it was decided to make transects at six or seven places, thus saving much time during a busy field season. The results were so interesting, and the method so satisfactory in vividly portraying distribution with change of habitat, that it was repeated on the Little Nemaha River, a neighboring stream of similar size and general direction of flow. Unlike the Weeping Water, which cuts a deep canyon, this stream has a broad flat floodplain.

The initial transect was made at the headwaters, about 2 miles northeast of Eagle. Here the unbroken (but pastured) prairie sloped to form a broad valley, in only the lower part of which an intermittent stream, dry nearly all summer, had begun to cut a channel. Salix nigra occurred as isolated individuals or in intermittent clumps (fig. I). Aside from a few $S$. amygdaloides and Populus del toides, no other trees were represented, and there were no shrubs. Similar vegetation prevailed for two miles, although the channel became well defined, often with steep banks 4 or 5 feet high.

' Nomenclature is according to BRITTON's Manual of the flora of the northern states and Canada. $2 \mathrm{~d}$ ed. 

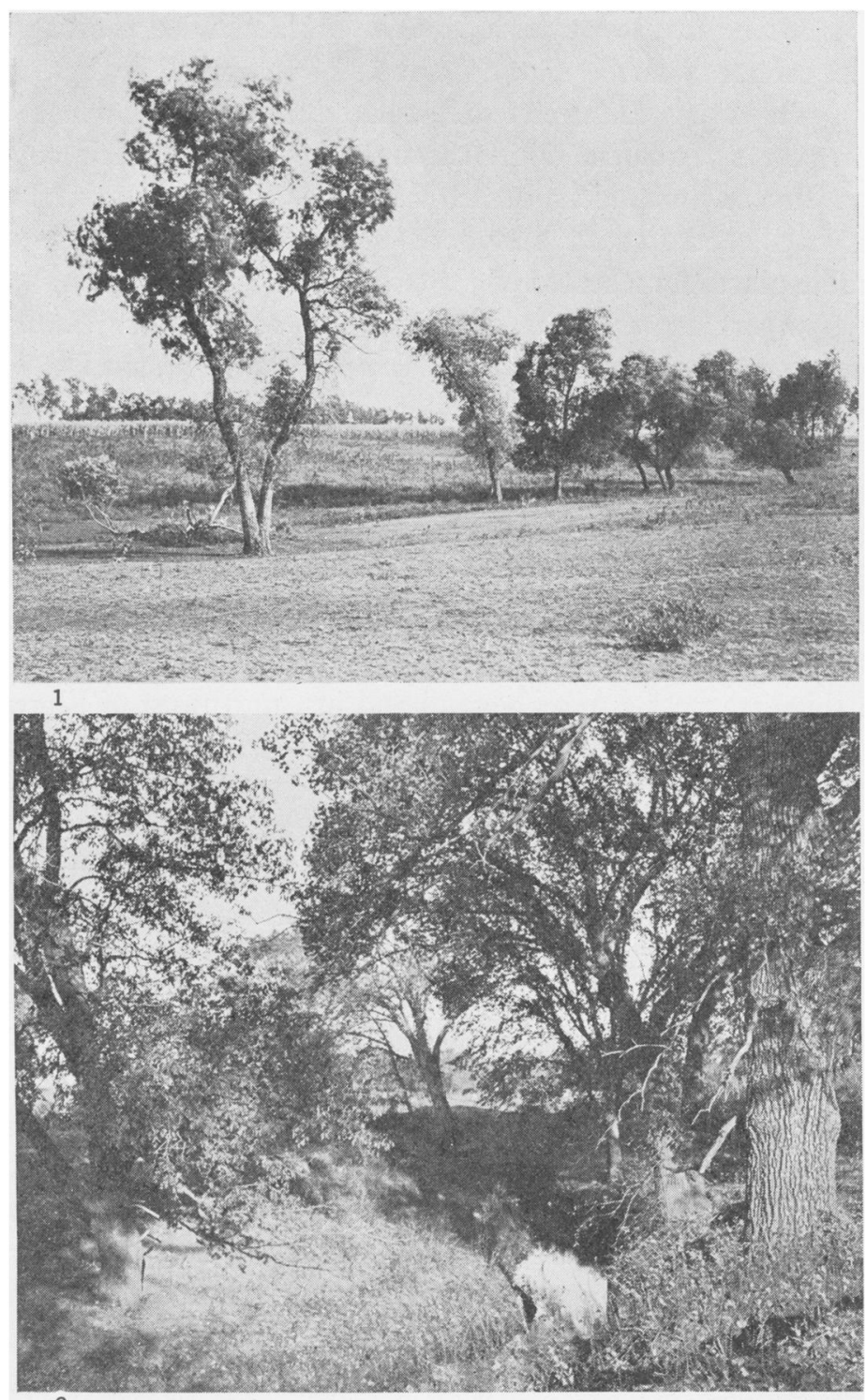

Figs. I, 2.-Fig. I, willows (Salix nigra) at headwaters of Weeping Water River; fig. 2, development of stream in transect 3; elms and cottonwoods characteristic trees. 
The second transect, which, like the first, included nearly a mile of the stream course, showed marked changes. The spring-fed stream ceased to be intermittent. It had cut banks Io-2o feet wide, and in places 8-ro feet deep, through the broad, prairie covered valley. In a few meanders, broad, somewhat wind protected sloping banks had been formed above the general channel. These were favorable places for a scattered growth of shrubs, chief among which were Symphoricarpos symphoricarpos, S. occidentalis, Sambucus canadensis, Prunus americana, and Amorpha fruticosa, the last growing down to the water's edge. Ribes gracile, Rhus glabra, Celastrus scandens, and Vitis oulpina were also found, but they were rare. Salix nigra was dominant, with considerable $S$. amygdaloides, the trees being much larger than before (some 2 feet in diameter) and much more abundant. A single small specimen of Fraxinus lanceolata and two of Prunus virginiana were the only other woody plants.

A third transect 2 miles beyond and just northwest of Elmwood gave a surprisingly large number of species. Here the creek, augmented by the water from laterals, was $2-8$ feet wide, and had a distance of 30-45 feet between the sloping banks, which were I $2-{ }^{-} 5$ feet high (fig. 2). The trees were no longer confined to the banks, but also sometimes occupied the floodplain bordering the channel for a distance of a few yards (fig. 3). They were Ulmus americana, $U$. fulva, Acer Negundo, Fraxinus lanceolata, and Salix nigra, the last in much fewer numbers than formerly. All the preceding frequently reached diameters of one and sometimes two feet. Populus deltoides was also quite abundant, the largest trees being 3-4 feet thick. Juglans nigra was found sparingly, only a few well developed trees occurring in the mile transect. Small trees of Morus rubra were infrequent. The more favorable conditions were further shown by the extensive growths of Symphoricarpos occidentalis and $S$. symphoricarpos, both on the banks and over the floodplains, where thickets 6 feet high were sometimes found. Ribes gracile, Sambucus canadensis, and Amorpha fruticosa were very common in both situations. Cornus asperifolia, Celastrus scandens, and Smilax hispida were less frequent, but Vitis oulpina was very common, sometimes with stems 3 inches thick. Rhus toxicodendron was common, Prunus ameri- 
cana less so; Rhamnus lanceolata and Rubus occidentalis were also found. In no place was the woodland belt more than a few rods wide.

In one portion of the transect, the stream in changing its course had left a south bank, I5-30 feet high, with a small pond near its base. Through this bank there entered a steep sided ravine, the whole offering a protected place for tree growth. On the sides of this ravine, and on the protected north-facing bank was found a scattered growth of Quercus macrocarpa, consisting of small trees mostly 5

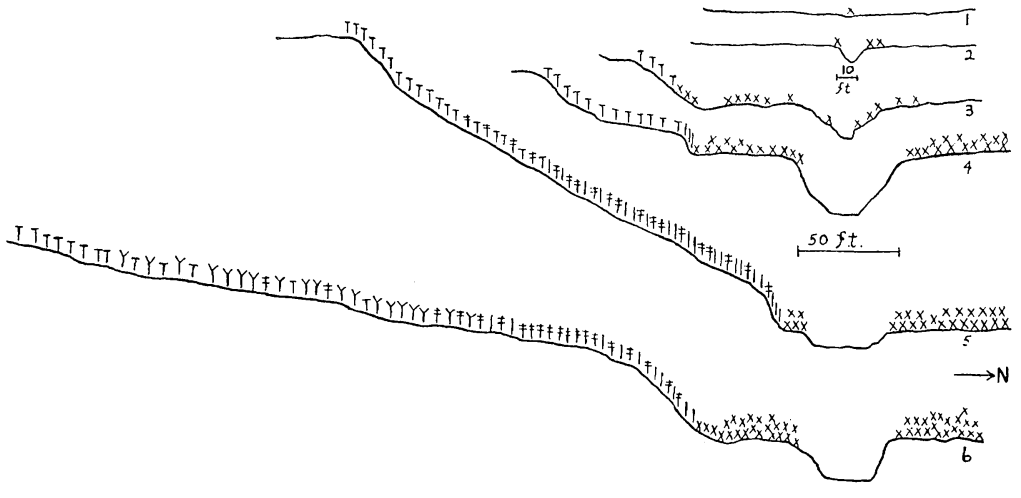

FIG. 3.-Profiles of Weeping Water valley, where transects I-6 were made: nos. 3-6 show only the south slopes bordering the valley; $X$, floodplain dominants; $T$, bur oak; $l$, linden; $\ddagger$, red oak; $Y$, shellbark hickory.

inches or less in diameter, and perhaps 35 feet in height. Associated with it was Hicoria minima of similar size, while on the protected lower slope and floodplain were fine specimens of Celtis occidentalis and Gleditsia triacanthos. Prunus serotina was also represented, but by small trees.

Quite in contrast with this area were stretches of the unprotected, windswept valley, which were nearly or quite destitute of woody vegetation. No Corylus americana was found, but this occurred quite abundantly along with the oak just northeast of Elmwood.

A fourth examination 3 miles farther down stream and just southwest of Wabash showed further development. Forest growth 
extended well over the eighth-mile wide floodplain, which was sometimes bordered on the south by steep slopes 20-50 feet high, covered with upland trees. Dense growths of Acer Negundo and Ulmus clothed the lowlands subject to overflow. The floodplain forest proper was composed of red and white elm, green ash, walnut, and box elder, and occasionally willows and cottonwoods. Bordering this, especially on steeper banks, were well developed specimens of Tilia americana, some I7 inches thick, elms, bur oak, and a little hickory. The oak especially, and the hickory in smaller numbers, spread up ravines and to the crests of hills, forming woodland to a distance of one-fourth mile from the stream (fig. 3). The increasingly favorable growth conditions were revealed in many ways. The floodplain trees were much more abundant, taller, of greater diameter, and the stands were denser. Walnut, ash, and elms, I-x.5 feet in diameter, were frequent, some of the elms being 4 feet thick. Hackberry, choke cherry, and honey locust, while not abundant, were found scattered throughout, while Gymnocladus dioica appeared for the first time. The linden, at first represented by small trees, became ro-- 2 inches in diameter in more favorable situations. Its range of habitat was very limited, however, being confined to the lower portions of steep slopes (fig. 3). Many of the oaks were 1.5 feet and some $2.5^{-3}$ feet in diameter. The wider range of Ribes gracile far back from the stream, together with its greater abundance and greater stature, is significant. Symphoricarpos spp. formed a shrubby undergrowth, alternating with thickets of Corylus in more favored and not too shady situations, and extended beyond the fringing oak forest. These, and Cornus, Sambucus, Rhamnus, Amorpha, and Prunus americana showed a more vigorous growth, as did also the lianas, Vitis, Celastrus, and Rhus toxicodendron, which sometimes climbed over the shrubs. Sambucus was especially abundant. Rhus glabra fringed the floodplain forest and extended far into the upland. The following shrubs and vines were also present, the first only in abundance: Smilax hispida, Parthenocissus quinquefolia, Xanthoxylum americanum, Rubus occidentalis, and Clematis missouriensis. These indicate the rapid development toward true forest conditions.

Four miles eastward the river begins to cut a canyon in the Pennsylvanian (Carboniferous) limestone. Just east of Weeping 
Water, 7 miles from the fourth transect, this reaches a depth of 120 feet. Here it is joined by Cascade Creek, also in a small canyon. Taking advantage of the shelter afforded by the rough topography, trees and shrubs have spread widely from the streams, and form a belt of timberland more than a mile wide. Only on the drier, windswept southwest slopes does the prairie hold forth, and experimental evidence shows that it is giving way slowly to shrubs and trees (fig. 4). Indeed, the habitat is so diversified that a distinct grouping of the members of the woodland community into associes has occurred. On the floodplains a mixed elm-walnut-ash associes is found; the lower slopes of the canyon banks are clothed with forests of red oak

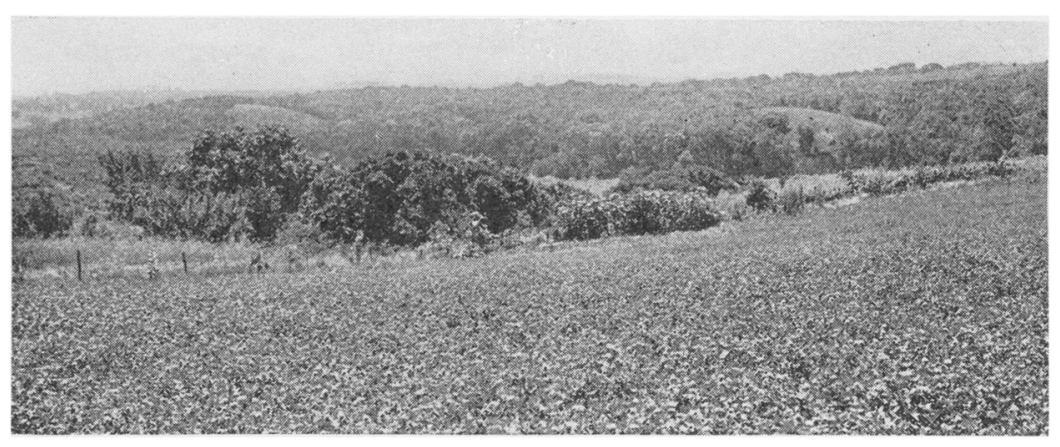

Fig. 4.-General view of woodland near Weeping Water (transect 5 ), showing grassland on thin soils overlying limestone on exposed southwest slopes.

and linden; the higher, as well as the protected south slopes, are clothed with bur oak and hickory. The last is fringed on its upper margins with a chaparral community, which extends under the open forest as a more or less suppressed layer. Upon the removal by cutting of any of these forest types (fig. 3), chaparral immediately springs into dominance.

FloodPLAIN AssociEs.-In this transect the floodplain is nowhere over one-third of a mile wide, in fact often less, but much better protected than heretofore. Fine specimens of red and some white elm, walnut, and green ash, 25-50 feet tall and io to over I8 inches in diameter dominate (fig. 5). Hackberry, box elder, and wild black cherry also make an excellent growth, while honey locust and Kentucky coffee tree are of less abundance. The chief shrubs are 
species of Symphoricarpos, gooseberry, wild black raspberry, and elderberry; while grape, smilax, bittersweet, and Virginia creeper are the characteristic vines. All are well developed. The soil of the floodplain forest is not especially rich in humus, since it is subject to overflow, and attendant conditions of aeration or subsequent drought exclude the growth of red oak and linden. Even a slight rise in topography is favorable to these more exacting trees, however, and the floodplain forest often gives way abruptly to them.

RED OAK-LINDEN ASSOCIATION.-Quercus rubra, not occurring in the preceding transect, here forms with Tilia americana a well defined association. Trees with diameters $8-{ }_{-} 5$ inches and about 50 feet tall are common. The annual precipitation has increased 2 or 3 inches as compared with that at the headwaters, humidity is much higher on these wind protected slopes, and soil moisture is more abundant. Humus is well developed, and rather typical mesophytic forest floor conditions have been attained (fig. 6), Ostrya virginiana being the characteristic secondary species. Ulmus fulva is common, especially nearer the floodplain, where Celtis, Juglans, and other floodplain species may occur infrequently. The density of the shade is shown by dead or attenuated bur oaks or hickories, which species flourish farther up the slopes. Euonymus atropurpureus, Staphylea trifolia, and Xanthoxylum americanum occur, with certain other shrubs, but as a whole undershrubs are few and layering is not well developed. The width of this forest community is variable, depending upon the slope, perhaps nowhere over 8 or io rods. Just as the lindens grow best on the lower banks, the red oak more nearly dominates farther up the slopes, and the transition to the bur oak-hickory community, although often abrupt, may be quite gradual.

BUR OAK-HICKORY ASSOCIES.- - This community was represented almost entirely by open growths of Quercus macrocarpa, Hicoria minima not being at all important (fig. 7). The trees were usually 6 inches or less in diameter, and only $35^{-40}$ feet tall, but excellent specimens were found in favored sites, forming an open woodland. The crowns were rather open. About half the forest was carpeted with Poa pratensis; the denser part was covered with a good leaf mulch, the grasses having been shaded out. Aside from a very few scattered hickory and an occasional box elder, with red elm or red 


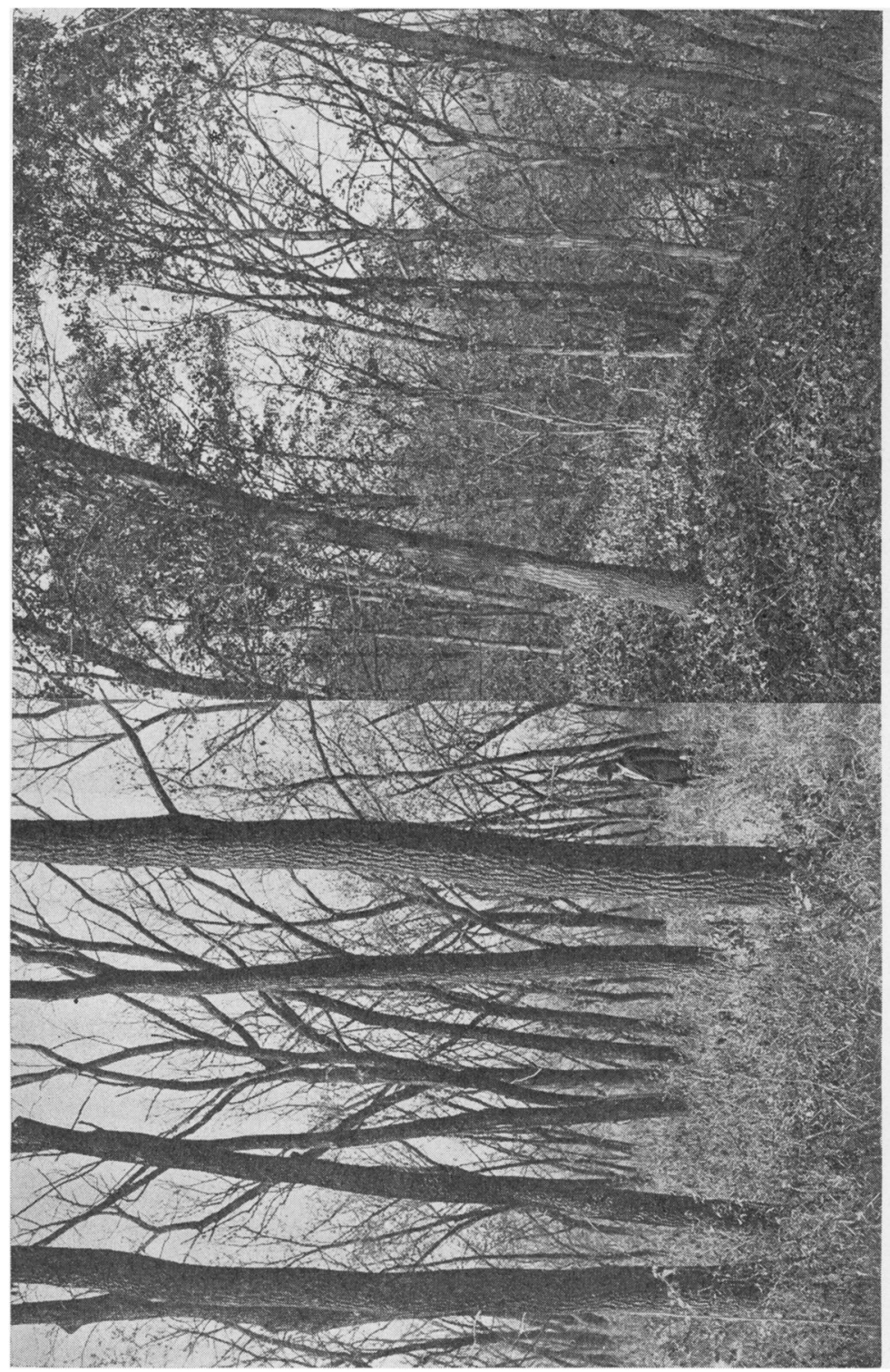

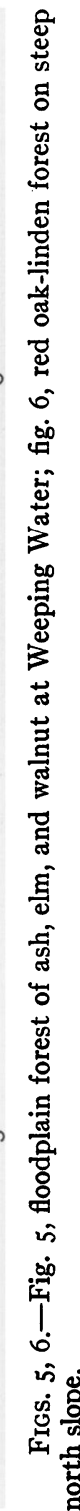


oak in the moister areas, practically no other trees occurred. Corylus, Symphoricarpos, Rhus glabra, and Cornus asperifolia were the characteristic undershrubs, although Rhamnus lanceolata, Sambucus canadensis, and Cornus stolonifera also occurred. The first was found only near the forest margins, or in extensive, dense thickets on cutover areas. Symphoricarpos, often poorly developed, was characteristic throughout; Cornus made its best growth in the open places or near the forest margins; while sumac was characteristically a fringing shrub, not enduring the shade well.

CHAPARRAL ASSOCIES.-In the chaparral proper Corylus showed its greater mesophytism by occupying the more sheltered areas, although it sometimes occurred on protected hilltops. Rhus glabra was more often found on the rocky hilltops and exposed slopes, while Symphoricarpos symphoricarpos and $S$. occidentalis occupied a somewhat intermediate position, but showed striking xerophytic tendencies. Associated with these shrubs, especially with the hazel, were Cornus asperifolia, Rhamnus lanceolata, Ribes gracile, Xanthoxylum americanum, and various lianas, especially Celastrus scandens and Smilax hispida, the whole often forming a dense tangle over extensive areas. The shrubs invade the grassland chiefly by their rhizomes and other methods of vegetative propagation. The grasses gradually succumb to these woodland outposts, because of unfavorable light relations, due in part to accumulations of débris. Forests of bur oak may follow in their wake. Thus most of this transect showed continuous woodland cover; ash-elm-walnut forests on the floodplains, red oak and linden on the well protected deeper soils of the northfacing slopes, bur oak in the drier soils above, perhaps with chaparral near and on the hilltops, giving way again to bur oak on the protected lower south-facing slopes, with red oak and linden in the ravines. As a whole the forests are young, however, and grassland often holds forth on the thin soils overlying the limestone on the exposed and windswept south and southwest hillsides (fig. 4).

The next transect was made about 8 miles farther eastward, one and one-half miles beyond Nehawka. Because of its proximity to the forests along the Missouri River, only 6 -8 miles farther east, and increasingly favorable growth conditions, the associes were better developed. In fact woodland would undoubtedly be continuous ex- 


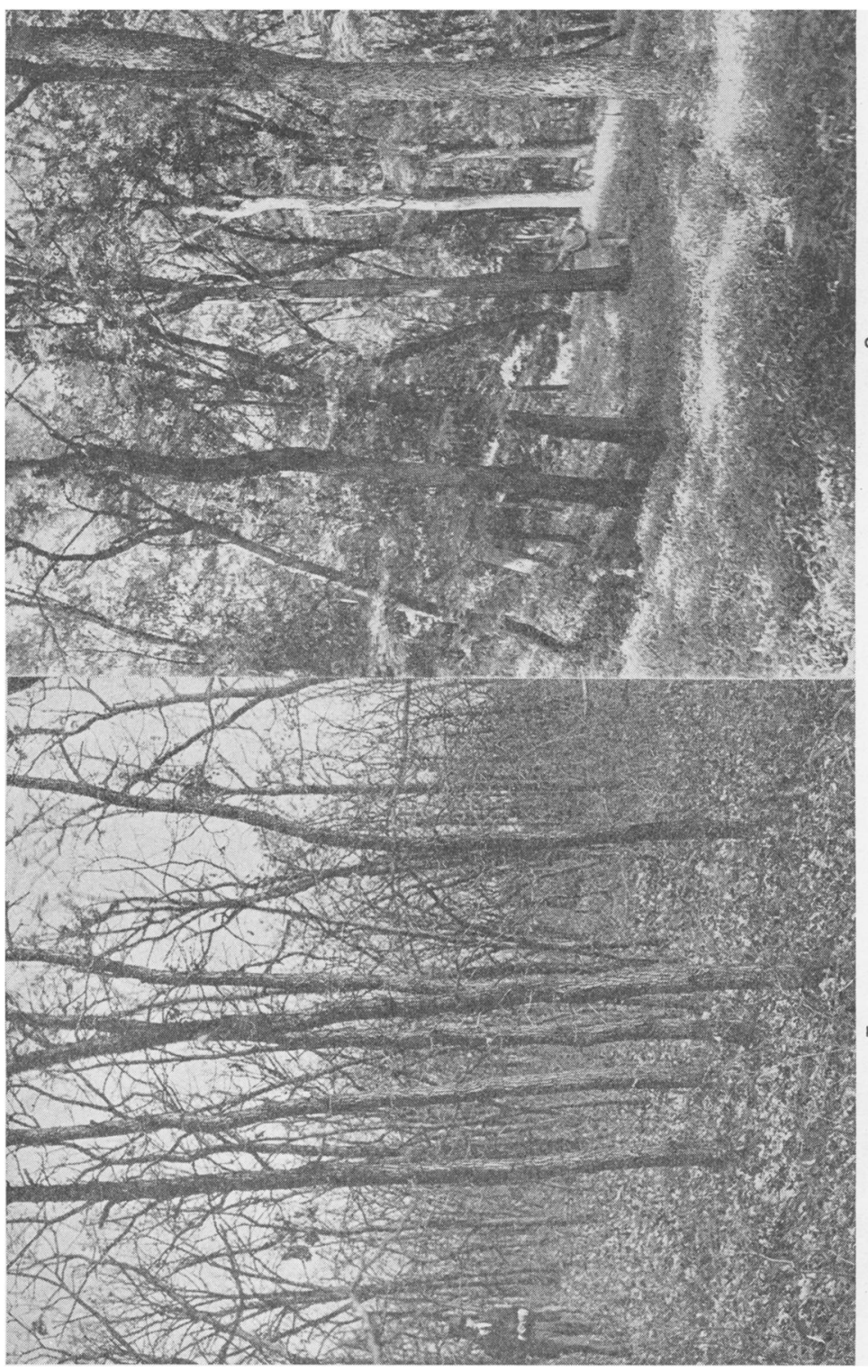

ฮँّ

$\infty$

घี

รี

प्ठ

苞

멱

荌

8

$\infty$

$\infty$

.

苛

है

㟒

。

윽

岁

-

.

$\leqslant$

응

济

1.

$\infty$

总

营 
cept for fires, grazing, cultivation, or other disturbances. The Weeping Water, augmented by numerous tributaries, here assumed the proportions of a rather large stream. The bed is ro- 5 feet wide, and in spring and early summer carries a rather large volume of water. Owing to the absence of deep canyons, it has a broad floodplain, extending in places nearly a mile across the valley floor.

The floodplain forest, as before, consisted largely of red elm, ash, and walnut; and hackberry, Kentucky coffee tree, and cottonwoods played an important part. The trees were much taller and of greater diameter than at Weeping Water (fig. 8). Among the dominants a diameter of $16-20$ inches was not uncommon, and specimens of elm and hackberry over 3 feet in diameter, breast high, were noted. Fine specimens of walnut logs from this area measured $18-32$ inches in diameter, and varied in age from 60 to 170 years. Several specimens of Gymnocladus I7 inches thick were found. Other trees characteristic of the floodplain were Salix nigra, S. amygdaloides, and Gleditsia triacanthos, large trees, but rather infrequent; Acer saccharinum, Acer Negundo, Prunus serotina, and Crataegus mollis, all rather infrequent.

On higher ground, and especially on north-facing slopes, the floodplain forest gave way to that of red oak and linden. As in the preceding transects, the linden grew best on steeper slopes, where fine, clean boled trees 60 or more feet tall and 10-20 inches in diameter occurred. It was not so limited in its range as heretofore, but extended well up over the gentle slopes, where with red oak it formed a dense forest canopy. Aside from ironwood other trees were rare. The deep litter of leaves and duff covered a rather mellow black soil, filled with fungus mycelia, but supporting only a scant shrubby and herbaceous vegetation of shade enduring species (fig. 9). This forest belt was of variable width, depending upon slope protection. On higher land, the dropping out of the linden was counterbalanced by the appearance of the shellbark hickory, which for a distance afforded a mixed red oak-hickory forest. Higher up the slopes, however, this soon gave way to nearly pure growths of hickory, which covered extensive areas (fig. Io). The trees were mostly 7 -Io inches in diameter. This forest was interposed between the red oaklinden association and the bur oak community (fig. 3). Undergrowth 
1925] WEAVER, HANSON, \& AIKMAN-WOODLAND VEGETATION
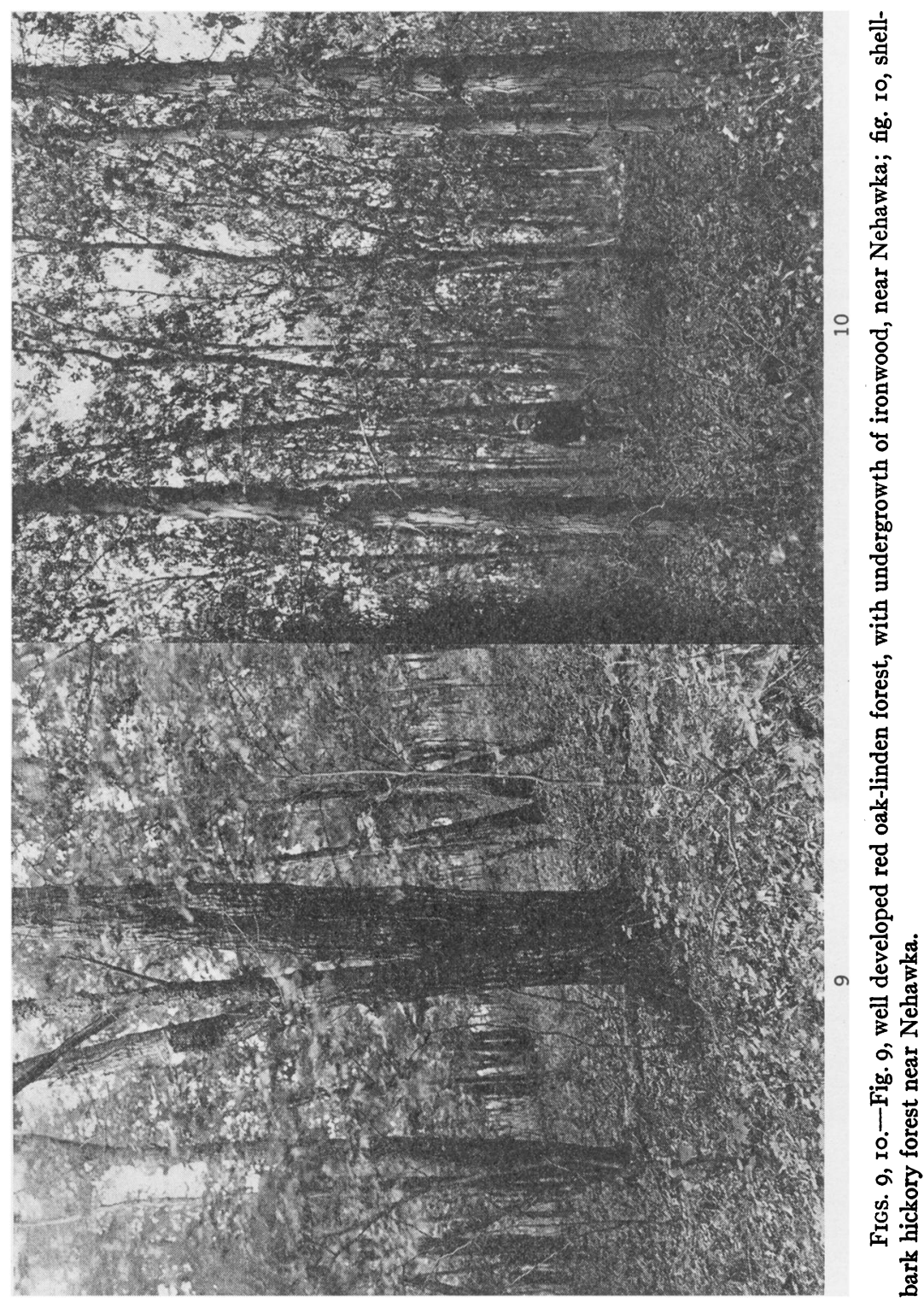
TABLE I

OCCURRENCE AND IMPORTANCE OF TREES AND SHRUBS ALONG WEEPING WATER River $(D$, Dominant; $S$, SUbdominant; $A$, abUndant; $F$, Frequent; $I$, INFREQUENT)

\begin{tabular}{|c|c|c|c|c|c|c|}
\hline \multirow{3}{*}{ Species } & \multicolumn{6}{|c|}{ Transect } \\
\hline & I & 2 & 3 & 4 & 5 & 6 \\
\hline & \multicolumn{6}{|c|}{ Trees } \\
\hline Salix $\operatorname{nigra} . \ldots \ldots \ldots \ldots \ldots \ldots \ldots$ & $\mathrm{D}$ & $\mathrm{D}$ & $\mathrm{S}$ & $\mathrm{S}$ & $\mathrm{S}$ & $\mathrm{S}$ \\
\hline Salix amygdaloides............. & $\mathrm{D}$ & $\mathrm{D}$ & $\mathrm{S}$ & $\mathrm{S}$ & $\mathrm{S}$ & $\mathrm{S}$ \\
\hline Prunus americana $\ldots \ldots \ldots \ldots \ldots \ldots$ & $\ldots$ & $\mathrm{S}$ & $\mathrm{S}$ & $\mathrm{S}$ & $\mathrm{S}$ & $\mathrm{S}$ \\
\hline 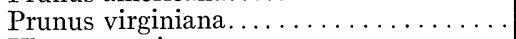 & $\ldots$ & $\mathrm{S}$ & $\mathrm{S}$ & $\mathrm{S}$ & $\mathrm{S}$ & $\mathrm{S}$ \\
\hline Ulmus americana $\ldots \ldots \ldots \ldots \ldots \ldots$ & $\ldots$ & $\ldots$. & $\mathrm{D}$ & $\mathrm{D}$ & $\mathrm{D}$ & $\mathrm{D}$ \\
\hline Ulmus fulva . . . . . . . . . . . & $\ldots$ & $\ldots \ldots$ & $\mathrm{D}$ & $\mathrm{D}$ & $\mathrm{D}$ & $\mathrm{D}$ \\
\hline Acer Negundo $\ldots \ldots \ldots \ldots \ldots \ldots \ldots$ & $\ldots$ & $\ldots \ldots$ & $\mathrm{D}$ & $\mathrm{D}$ & $\mathrm{S}$ & $\mathrm{S}$ \\
\hline Fraxinus lanceolata............. & .. & $\ldots \ldots$ & $\mathrm{D}$ & $\mathrm{D}$ & $\mathrm{D}$ & $\mathrm{D}$ \\
\hline Juglans nigra............... & & & $\mathrm{S}$ & $\mathrm{D}$ & $\mathrm{D}$ & $\mathrm{D}$ \\
\hline Quercus macrocarpa............ & & $\ldots$. & $\mathrm{S}$ & $\mathrm{D}$ & $\mathrm{D}$ & $\mathrm{D}$ \\
\hline Populus deltoides. $\ldots \ldots \ldots \ldots \ldots \ldots \ldots$ & $\ldots$ & $\ldots .$. & $\mathrm{S}$ & $\mathrm{S}$ & $\mathrm{S}$ & $\mathrm{S}$ \\
\hline 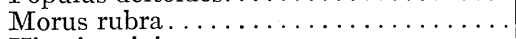 & $\ldots$ & $\ldots$ & $\mathrm{S}$ & $\mathrm{S}$ & S & $\mathrm{S}$ \\
\hline Hicoria minima.............. & $\ldots$ & & $\mathrm{S}$ & $\mathrm{S}$ & $\mathrm{S}$ & $\mathrm{S}$ \\
\hline Celtis occidentalis $\ldots \ldots \ldots \ldots \ldots \ldots$ & ... & $\ldots$ & $\mathrm{S}$ & $\mathrm{S}$ & $\mathrm{S}$ & $\mathrm{D}$ \\
\hline Gleditsia triacanthos $\ldots \ldots \ldots \ldots \ldots \ldots$ & $\ldots$ & $\ldots$. & $\mathrm{S}$ & $\mathrm{S}$ & $\mathrm{S}$ & $\mathrm{S}$ \\
\hline Prunus serotina $\ldots \ldots \ldots \ldots \ldots \ldots \ldots$ & & & $\mathrm{S}$ & $\mathrm{S}$ & $\mathrm{S}$ & $\mathrm{S}$ \\
\hline 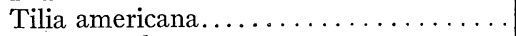 & & & & $\mathrm{S}$ & $\mathrm{D}$ & $\mathrm{D}$ \\
\hline 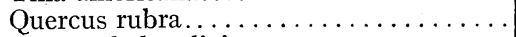 & & & & & $\mathrm{D}$ & $\bar{D}$ \\
\hline Gymnocladus dioica $\ldots \ldots \ldots \ldots \ldots \ldots$ & & & & $\mathrm{S}$ & $\mathrm{S}$ & $\mathrm{S}$ \\
\hline Ostrya virginiana $\ldots \ldots \ldots \ldots \ldots \ldots \ldots$ & & & .. & $\ldots$. & $\mathrm{S}$ & $\mathrm{S}$ \\
\hline Amelanchier canadensis............ & & & & & S & $\mathrm{S}$ \\
\hline Salix interior. . . . . . . . . . . . . & & & & & $\mathrm{S}$ & $\mathrm{S}$ \\
\hline Hicoria ovata $\ldots \ldots \ldots \ldots \ldots \ldots \ldots \ldots$ & & & $\cdots$ & $\cdots$ & $\ldots$ & $\mathrm{D}$ \\
\hline Quercus velutina................. & & & . & $\ldots$ & $\ldots$ & $\mathrm{S}$ \\
\hline \multirow[t]{2}{*}{ 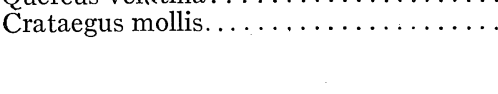 } & & & & & & $\mathrm{S}$ \\
\hline & \multicolumn{6}{|c|}{ Shrubs } \\
\hline Symphoricarpos symphoricarpos.... & & A & A & A & A & A \\
\hline Symphoricarpos occidentalis........ & & A & A & $\mathrm{A}$ & A & A \\
\hline Sambucus canadensis............ & & $\mathrm{F}$ & $\mathrm{F}$ & $\mathrm{A}$ & $\mathrm{F}$ & $\mathrm{F}$ \\
\hline Amorpha fruticosa............... & & $\mathrm{F}$ & $\mathrm{F}$ & $\mathrm{F}$ & $\mathrm{I}$ & $\mathrm{I}$ \\
\hline Ribes gracile.................. & .. & $\mathrm{I}$ & $\mathrm{F}$ & $\mathrm{A}$ & $\hat{A}$ & A \\
\hline Celastrus scandens. . . . . . . . . . . & . & $\mathrm{I}$ & $\mathrm{I}$ & $\mathrm{F}$ & A & A \\
\hline 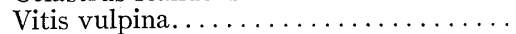 & & I & A & $\mathrm{A}$ & A & A \\
\hline Rhus glabra................. & & I & $\mathrm{F}$ & A & A & A \\
\hline Cornus asperifolia $\ldots \ldots \ldots \ldots \ldots \ldots$ & & & I & $\mathrm{F}$ & A & A \\
\hline Rubus occidentalis.............. & & & $\mathrm{I}$ & I & $\mathrm{F}$ & $\mathrm{F}$ \\
\hline Smilax hispida....... & & & $\mathrm{I}$ & $\mathrm{A}$ & A & $\mathrm{A}$ \\
\hline Rhus toxicodendron $\ldots \ldots \ldots \ldots \ldots \ldots$ & & & $\mathrm{F}$ & A & A & A \\
\hline Rhamnus lanceolata............. & & & $\mathrm{I}$ & $\mathrm{F}$ & A & A \\
\hline Corylus americana..$\ldots \ldots \ldots \ldots \ldots \ldots$ & & & & $\mathrm{F}$ & $\mathrm{A}$ & A \\
\hline Parthenocissus quinquefolia......... & & & . & $\mathrm{I}$ & $\mathrm{F}$ & $\mathrm{F}$ \\
\hline Xanthoxylum americanum............ & & & & I & $\mathrm{F}$ & $\mathrm{F}$ \\
\hline Clematis missouriensis. . . . . . . . & & & & I & I & $\mathrm{I}$ \\
\hline Euonymus atropurpureus. . . . . . . . . . . & & & & $\ldots$ & $\mathrm{I}$ & I \\
\hline Staphylea trifolia................. & & & & & $\mathrm{I}$ & $\mathrm{I}$ \\
\hline 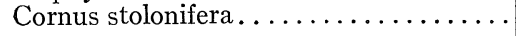 & $\cdots$ & $\ldots$ & $\cdots$ & $\ldots$ & $\mathrm{I}$ & $\mathrm{I}$ \\
\hline
\end{tabular}


in the two communities was not markedly different, although both the shrubby and herbaceous layers were better developed in the bur oak forest, where shade was less dense. Symphoricarpos was the chief shrub, although Cormus and Corylus occurred sparingly. Usually the leaf mulch and shade caused the disappearance even of blue grass, which formed a rather characteristic carpet in more open bur oak forest. The intolerance of the bur oak was often shown by dead trees only a few inches in diameter where the hickories occupied the territory.

Bur oak forest, often with a considerable admixture of bitternut hickory, also covered wide areas. Here, too, the trees were of greater stature than at Weeping Water, but the forest structure was very similar. Chaparral in cutover areas was very well developed. All of the species found in the preceding transect again occurred, usually in increased numbers, and their enumeration for the different communities is quite unnecessary. The almost total absence of Quercus velutina was rather surprising. In the better developed forests along the Missouri River southward at Peru, it occupies an intermediate position between the bur oak and shellbark hickory and red oak.

For several miles east of this transect, the widening floodplain has been cleared of timber and the land is cultivated, often quite to the banks of the stream; hence further study was not made. Such a clearing will form a rather effectual barrier to tree migrants up stream. The occurrence and importance of the various trees and shrubs in the several transects are summarized in table I.

\section{Studies along Little Nemaha River}

The Little Nemaha has its headwaters (north fork) 2 miles southeast of Cheney and about ro miles south and ro miles west of those of the Weeping Water. Its southeastern course roughly parallels that of the latter, approximately $15^{-20}$ miles southward.

Conditions in the first transect were practically identical with those already described, Salix nigra alternating with $S$. amygdaloides, in a broad valley with practically no channel or merely the beginnings of a ditch.

A second transect, 2 miles eastward, was made across prairie land, where a meandering stream with banks $2-3$ feet high was 
usually dry in late summer. Low meadow and swamp land about 7 rods wide occupied a part of the area. The dominant tree was Salix nigra, which was fairly abundant and 8-14 inches in diameter, but S. amygdaloides of equal size was found. Populus deltoides was less abundant. Amorpha fruticosa and Sambucus canadensis were both quite abundant, the former attaining a diameter of 2 inches. Vitis vulpina, with a similar stem diameter, was found growing to a height of 30 feet on some of the willows. A single Ribes gracile also occurred. A few Acer saccharinum and $A$. Negundo had escaped from neighboring groves, as had also one or two Gleditsia triacanthos and Fraxinus lanceolata. All were small trees. A thicket of Prunus americana in a ravine on a neighboring hillside was fringed with Rhus glabra, and sheltered a few Ribes gracile and Rubus occidentalis.

Two and one-half miles eastward and just south of Bennett, a third examination was made. The stream here had a well defined channel, with a depth of 8 feet, with running or standing water, except in the driest times. Because of the gentle gradient, the valley was filled with ox-bow loops, so that from a distance the woodland appeared to be 8 or to rods wide. In reality it did not get far beyond the protecting stream banks, which sloped back gradually on depositing shores. A rather precipitous ridge $20-30$ feet high bordered the floodplain on the south, and furnished much protection from the wind. Salix nigra had entirely disappeared, the dominant floodplain trees being Fraxinus lanceolata, Acer Negundo, and Ulmus americana. Secondary species were $U$. fulva, Celtis occidentalis, and Gleditsia triacanthos. The shrubs were Symphoricarpos symphoricarpos and $S$. occidentalis, about equally abundant. They formed intermittent areas on the lowland and extended well up on the high ridge. Scattered bushes of Ribes gracile were common throughout the lowland. Vitis vulpina, and to a less extent Parthenocissus quinquefolia were rather common. A morpha fruticosa occurred sparingly. A deep, sheltered ravine, extending into the high bordering southern ridge, formed a locally protected area, in which were found Cornus stolonifera, Euonymus atropurpureus, Prunus americana, Rhus glabra, and Rubus occidentalis, all abundant; and Clematis virginiana, Rhamnus lanceolata, Rhus toxicodendron, Prunus demissa, and Smilax hispida in smaller numbers. The last was also found on the 
floodplain. Near the lower end of the mile transect two small Quercus macrocarpa and a single Juglans nigra were observed. A mile below, at the junction of the three forks, bur oak was abundant.

A fourth transect was made 2 miles southwest of Palmyra, and about 6 miles east of the third transect. Here the stream had shallow running water $4^{-8}$ feet wide during the dry late summer. The rather steeply sloping banks were 8-20 feet high, while the floodplain varied from one-eighth to nearly one-fourth of a mile in width. The lower portion next the stream for a distance of $\mathrm{x}-5$ rods was subject to overflow, while much of the remainder had been given over to the cultivation of crops. The dominant floodplain trees were red and white elm and green ash, with an abundance of box elder in the more open parts especially subject to overflow. Black walnut and hackberry were both very abundant. When growing in fairly close stands fine specimens of elm, walnut, and hackberry, 50-60 feet tall and from $x$ to over 2 feet in diameter, were not infrequent. Thus the dominants had increased one-third to one-half in height. Species of less importance were cottonwood (locally abundant), black willow, and honey locust. Both species of Symphoricarpos were abundant everywhere, indicating by their stature much more favorable growth conditions than formerly. Gooseberries, elder, raspberry, grape, Virginia creeper, poison ivy, and smilax were found throughout, all being well developed where the shade was not too dense. Dogwood and burning bush were also widely distributed.

A considerable portion of the floodplain was sheltered on the south by a bank extending 20-40 feet above the general level. Here Quercus macrocarpa and Hicoria minima formed almost pure stands. Many of the oaks were 6-ro inches in diameter, the hickory being slightly smaller and not getting so far up the hillside as the oak. Beneath the oak and hickory was a well developed layer of Cornus asperifolia, Corylus americana, Ribes gracile, and Rubus occidentalis. Rhamnus lanceolata was represented sparingly. Symphoricarpos spp. and Rhus glabra extended from the forest edge to form dense chaparral on the drier upper slopes, which were treeless. A few other trees were found, but none were large specimens. These were Morus rubra, Prunus demissa (somewhat abundant), Gymnocladus dioica, and Aesculus glabra. The last two were found in scattered small 
clumps only in the most sheltered parts of the forest. Their presence indicated a considerable degree of mesophytism. This was further shown by the invasion of elms, hackberries, and others into the lower slope occupied by the bur oak and hickory.

Upon leaving this area the floodplain gradually widened to half a mile, and then to over a mile in extent, the bordering hills thus usually being far removed from the present tree belt (fig. II). Two factors had entered to disturb the forests. A drainage channel had been cut in the valley from Syracuse to the Missouri River, a distance of approximately 40 miles, thus leaving much of the old channel dry. The most destructive disturbance, however, had been

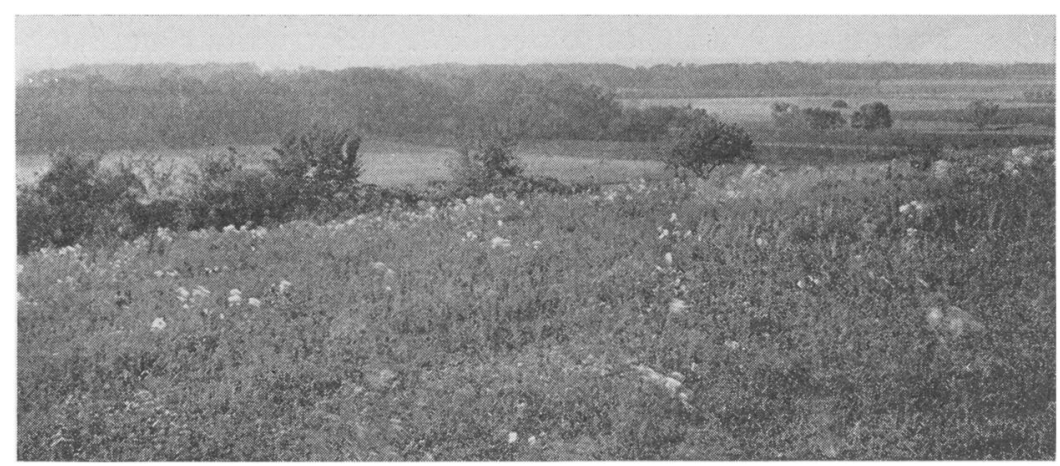

Fig. I I.-View along the broad floodplain of Little Nemaha below Syracuse

brought about by the clearing of the forests and the cultivation of the broad fertile floodplain; in fact, it was usually tilled to within a few rods of the stream. Hence much of the remaining vegetation was on land subject to overflow, and only fragmentary sites of oakhickory were to be found. Extended examination of two transects, the first one mile southwest of Syracuse and another just west of Talmage (which is 25 miles southeast of the Palmyra transect), as well as a third at an intermediate point, showed little change in the floodplain species. As before, elms, ash, walnut, and hackberry were most abundant, with box elders in the newer areas more subject to overflow. Honey locust and willows often played an important rôle. All were nearly or quite as well developed as in the most sheltered portion of the preceding transect, some being even taller and of 
greater diameter. Their general distribution over the floodplain, and the greater continuity of the forest, revealed more favorable conditions for growth. This was further shown by an excellent growth of bur oak and hickory on certain south-facing slopes above the floodplain. With these were found all the shrubs and lianas before enumerated as characteristic of the associes. Kentucky coffee trees and honey locusts were much larger than before, as were also the hickories on the higher floodplains. In general, all the shrubs and lianas characteristic of the floodplain had made a much more vigorous growth, a phenomenon especially prominent in bordering plum thickets. Robinia pseudacacia was the only new species found, and this was very local, having escaped from cultivation.

The river continues its southeastern course, meandering in a floodplain $\mathrm{x} \cdot 5^{-3}$ miles wide. The land rises without precipitous bluffs to the old dissected loess plain. No extensive tree growth, except that on the uncultivated remnants of the floodplain, was seen for a distance of ro miles below the last transect. Five miles southeast of Brock, where Rock Creek enters from the north, considerable tracts of undisturbed woodland were found. This stream, with a floodplain one-fourth mile wide, is bordered by hills which rise somewhat abruptly 50-60 feet.

The floodplain forest dominants, as at Weeping Water, were Ulmus fulva, Fraxinus lanceolata, and Juglans nigra. Secondary species and the undergrowth of shrubs were also similar. On the lower, moist slopes bordering the floodplain, a mixed forest of red oak, shellbark hickory, and black oak occurred. Only in limited areas on the longest slopes did a segregation into rather distinct communities occur. These, however, were sufficiently pronounced to show clearly the dominance of the red oak on the best developed, most mesophytic areas. The shellbark hickory, often intermixed with black oak, or the latter forming an upper portion to the black oak-hickory community, occurred above the red oak zone. These trees were $10-20$ inches in diameter, and $45-55$ feet in height. The higher slopes, even those quite exposed, were clothed with a continuous cover of bur oak and bitternut hickory, the latter being much more abundant than anywhere along the Weeping Water River. Shrubs forming the undergrowth in the woodland and fringing its 
borders were of the same species, and quite as abundant as at the Weeping Water station (transect 5). In general, the development of the plant communities, owing to less shelter afforded by the more regular topography, was poorer than at the latter station.

Twelve miles farther down the stream, and only 3 miles from its junction with the Missouri, another favorable place for study was afforded by the meandering stream, with its accompanying floodplain forest, flowing close to the foot of a rather steep north slope. Avoiding undue repetition, it may be noted that here the forest communities were of the same type and of similar distribution to those at Nehawka. The trees and shrubs were fully as well developed, and the black oak, which was rare at Nehawka, here played the rôle of a dominant. Further studies would undoubtedly reveal other woody species along the lower course of the Little Nemaha, but none of any ecological significance.

\section{Discussion and conclusion}

From these data it may be seen that a series of wide transects made at carefully selected intervals along the course of a stream reveals in a striking manner the appearance of species in the general sequence of their ecological requirements and their later development into forest communities.

The pioneer trees at the stream sources are those with light, windblown seeds, such as willow, cottonwood, elms, box elder, and ash. Farther down stream, where a floodplain with protecting banks occurs, trees appear which spring from large rodent-carried fruits, such as walnut, bur oak, bitternut hickory, honey locust, etc. The first shrubs and lianas to occur near the stream sources, with the single exception of Amorpha fruticosa, all have showy edible fruits which are readily carried by birds. Such are species of coral berry, elder berry, gooseberry, bitter-sweet, grape, dogwood, raspberry, greenbriar, etc. Cherry, plum, mulberry, and hackberry, all appearing relatively early, migrate in a similar manner. Of course the factor of migration, although an essential one, is of little significance unless it is followed by eccesis, that is, germination, growth, and reproduction. Many forest trees, such as linden, red oak, and shellbark hickory, are clearly too demanding in their habitat requirements to pioneer against grasses, and migration alone would be of 
little consequence. Chaparral and less mesophytic forests, such as bur oak, regularly precede them in their up-stream invasions.

A study of the sequence of the appearance of trees and shrubby species along stream courses originating in prairie, throws much light upon their ability to tolerate unfavorable growth conditions; for here the balance between forest and grassland is so delicate that a little higher water content, a slightly greater humidity, protection from drying winds, etc., throws the balance in favor of tree growth, while the reverse conditions exclude it. Rate of growth in the several transects, as revealed by width of annual rings, will add much to the story of adaptation to habitat, and form an excellent measure of the growth conditions in the several transects as integrated by the living plant.

At first invaders may appear in mictia, willow, box elder, elm, walnut, oak, hickory, and linden, all in the one rather undiversified habitat, the irregular floodplain. Soon, however, as the stream cuts its channel with a lower floodplain subject to overflow, a higher floodplain, and sloping banks and bluffs, the trees are promptly grouped into definite communities. The intolerant willows largely disappear; box elder clothes the lower floodplain; ash, elms, and walnut cover the upper; and linden, oaks, and hickories are found on the higher ground. Thus a stream course cutting deep canyons has the most diversified forests. One of the most interesting contrasts between the Weeping Water and the Little Nemaha was the rapidity of this early sorting into definite communities in the first, and the much greater distance traversed before this occurred along the latter stream. Well developed bur oak forests were found only 6 miles from the headwaters of the Weeping Water, but I I miles down the Nemaha. Similarly, the red oak-linden community was well defined I 8 miles from the headwaters of the former stream, but down stream a distance of 60 miles on the Little Nemaha.

The behavior of woodland species as revealed by this study, confirms the view that while the woodland along the upper portions of the streams is undoubtedly postclimax, that along their lower course is a part of the generally undeveloped woodland of the subclimax prairie.

UNIVERSITY OF NEBRASKA

Lincoln, NEB, 